\title{
Role of Credit Risk in Performance difference between A and B Class Banks in Nepal
}

\author{
Hari Gopal Risal ${ }^{*}$ \\ Suprima Poudel ${ }^{\#}$
}

\begin{abstract}
This paper explains the performance differences between $A$ and $B$ class financial institutions arising from credit risk. The dynamic panel data from 2008 to 2019 has been considered from all 28 commercial banks and 11 national level development banks for analysis. Arellano Bond method has been performed to control the unobserved heterogeneity and to reduce biasness in the parameter estimation as they have both cross sectional and time dimensions. The results have shown clear differences in credit risk status between $A$ class and B class bank with all the parameters except for Return on Assets (ROA). The results show that the A class commercial banks are less vulnerable than the $B$ class bank as measured by Standard deviation of ROA ( standard deviation of return on equity (SDROE) both, yet offer substantially higher ROE and fairly higher NIM.
\end{abstract}

Findings suggest that the past performance BFIs, regardless their classes, are capable enough to predict their future performance as all lag variables are significant. Development banks are advised to focus on maintaining appropriate credit to deposit ratio $(C D R)$ as it has been affecting most of the performance indicators whereas, commercial banks are advised to monitor their loan loss provision to total loans and advances (LLPTLA) for better performance. The control variables have been found to have negligible effect on performance of banks yet higher inflation deteriorates the performance even at a small amount. Further, contradictory findings on influence of real gross domestic product $(G D P)$ growth with the performance demands a need of further research.

To recapitulate, the credit risk plays a vital role in performance of banks in Nepal and A class banks safer with returns.

Key Words: credit risk; performance of banks; return on assets and equity

JEL Classification: C23, E58, F65, G21

* Assistant Professor, Finance, Kathmandu University School of Management, Nepal, E-mail: harigopal@kusom.edu.np

\# MBA Scholar, Kathmandu University School of Management, Nepal, E-mail: 19127_suprima@kusom.edu.np 


\section{INTRODUCTION}

Financial institutions are pivotal component of every economy. The financial system provides a backbone for the nation and instills strength to overcome economic turmoil. Thus, the risks of banks and financial institutions are of major concern. Banks and financial institutions face two major kinds of risks: Financial risk and Non- Financial Risk (Naeem, 2014). Though there is significant number of risks that BFIs face, many incidents in history have shown that credit risk is one of the most crucial ones due to loans being major portion of banks assets (AlTamimi \& Al-Mazrooei, 2007). The 2008 financial crisis which hit the entire globe was an evidence to depict the consequence of credit mismanagement. Basel (2010a) has brought into limelight the root cause behind the economic and financial crisis in 2007 that were the on and off-balance sheet leverage, poor capital ratios and insufficient liquidity as a result of which the banking system was unable to absorb the systematic risk and credit losses (BASEL Committee on Banking Supervision, 2010, b). This gave a rise to the need of amendment in BASEL principles and birth of BASEL III focusing on credit aspect and to strengthen the bank's portfolio.

The policies, which define the risk absorption capacity, vary among banks, influencing the type of credit options they offer and type of assets they invest which directly or indirectly impacts their level of profitability (Aliu \& Sahiti, 2018). Credit is the major factor on which the performances of banks depend. Credit risk doesn't end in it. It results in birth of number of other risks such as operational risk, liquidity risk, etc. (Malla, 2017) Thus, various steps are being taken to neutralize the consequences arising from excessive credit risk. Although a general notion in finance emphasizes on higher returns as the outcome of higher risk, the actual outcome may not hold true in many cases. For instance, the financial crisis is a vividly proven fact. In this context, the necessity of this study arose to complement the existing studies on impact of credit risk to performance of Nepalese development Banks alongside comparative analysis of credit risk between Commercial and Development banks. The latest and sufficient data size with major five performance indicators comprising returns for varying stakeholders with their variability further complements to existing insufficient coverage for generalizing the results. This study explores the question "Does Credit Risk influence the performance of A and B class institutions in Nepal? Further, this study identifies the difference in impact of credit risk on performance of $\mathrm{A}$ and $\mathrm{B}$ class banks and financial institutions (BFIs).

\section{REVIEW OF LITERATURE}

Credit risk has been defined as, "the chances that a borrower will not be able to meet the obligations as per the agreed terms" (BASEL committee, 2000). It arises 
when borrowers can't meet their financial obligation toward a BFI as agreed in the terms and conditions (Fredrick, 2012). It can be referred as risk of failure on part of borrower to meet terms of line of credit with bank (Nawaz, Munir, Ahad, Afzal, Asif, \& Ateeq, 2013).

Bhattarai (2015) examined the performance of commercial banks over a period of 6 years (i.e., 2010-2015) with only 14 banks as sample representing banking industry. ROA is taken as a proxy of performance, the dependent variable with independent variables Capital Adequacy Ratio, Non-Performing Loan Ratio, and Cost per Loan Assets, Cash Reserve Ratio and Bank size. With the Pooled regression analysis, Non-Performing Loan Ratio is found to have negative relation to bank performance whereas Cost per Loan Assets having positive impact. With an addition of Return on Equity, Alshatti (2015) studied the effect of credit risk management on financial performance of commercial banks in Jordan. The study covering 9 years (i.e., 2005-2013) with 13 Jordanian commercial banks had similar independent variables such as CAR, Credit interest/ Credit facilities ratio, Facilities loss/Net facilities ratio, Facilities loss/Gross facilities ratio, Leverage ratio, Non-performing loans/Gross loans ratio). Using the descriptive and F-Fisher analysis with panel squares method and cross sectional analysis; NPLR is found to have positive, and CAR have no relationship with ROA. Interestingly, Leverage ratio is found to have adverse impact when measured by ROA and no impact on ROE.

Aliu and Sahiti (2016) carried out a close yet different study to check the impact of risk management on Bank's profitability where four largest banks, operated in Kosovo, covering ten years (i.e., 2006-2015) with ROE a proxy for profitability whereas Risk asset ratio and non-performing loan ratio as measures of credit risk. Using the pooled OLS and Multivariate Linear Regression, study has found the ROE and RAR to have negative relationship and vice-versa with NPLR. Linear regression validated the RAR and profitability relationship while contradicting the fining of multivariate analysis on NPLR and profitability.

Poudel (2018) identified the major indicators of credit risk in Nepalese Commercial Banks covering a period from 2002/03 to 2014/15 with 15 commercial banks. One way fixed Effect Model was used to analyze the obtained data. The relationship of liquidity was found to be significantly positive with credit risk whereas Capital Adequacy ratio and interest spread were found to have significant negative impact. Bank size is found to have no clear relationship and GDP is found to have negative but insignificant relationship with Credit risk.

Almekhlafi, Kargbo, and Hu (2016) have used secondary data from 1998-2013 of top most 6 banks in Yemen that cover around 50\% of banking system assets of the nation. They have used the common constant and the fixed effect model and 
evidenced that NPL erodes bank profitability alongside positive correlation between LA and ROA. Furthermore, study has depicted the negative relationship between NPL, Inflation and GDP growth with ROA. Another study by Isanzu (2017) identified the causal relationship between Non-performing Loan Ratio and bank performance (i.e. ROA). One unit increase in NPL decreases ROA by 0.10 units other regressors remaining constant whereas 1 unit increase in Capital adequacy increases ROA by 0.06 unit indicating positive and strong relationship. Furthermore, relationship of impaired loan reserve to gross loan on return on asset was also found to be negative whereas, ratio of loan impairment charges on ROA was found to be positive. The study considered data from 2008-2014 from Chinese Banks and used balanced panel regression model to derive the findings.

Parab and Patil (2018) analyzed panel data of 40 banks of 16 years listed in Bombay Stock Exchange in which Gross Non-Performing Asset ratio, Loan Loss Allowance to Total Advances, Capital Adequacy Ratio, Credit Deposit Ratio, Loan Loss Allowance to Non-Performing Assets, Loan Loss Allowance to Assets, and Advances to Assets. ROE, ROA and NIM were used as proxies for Performance. The research used Random effect panel GLS and found that CDR has positive and significant relationship with all performance indicators. The study assesses credit risk and performance of Private and Public Banks in India using the Panel Approach.

(Olugboyega, Babatunji, Jayeola, \& Tobi, 2018), have considered 10 Nigerian Listed Deposit Money Banks to study the effect of credit risk management on their financial performance. Using the Random effect model of regression, the study found NPLTLR, NPLTDR and CAR to have significant relationship with performance measured by ROA and ROE.

Saeed (2016) presents links between bank profitability and credit risks considering top five UK commercial banks using data from 2007 to 2015 . It states that all factors i.e. Impairments divided by Total Loans, NPL divided by Total Assets, Bank size, Growth in bank interest income and leverage ratio have positive relationship with ROA. However, in case of ROE Impairments divided by Total Loans has negative whereas other factors have positive relationship with it.

Kani (2017) has taken samples from 2007-2015 of 20 banks and applied individual effects model. The study has shown that in WAEMU countries, profitability were not directly related to economic situation rather NPLR and LLP was found to have negative relationship with the profitability indicator, i.e. ROA. 


\section{CONCEPTUAL FRAMEWORK}

Based on the various literature and empirical evidence, the following framework for has been used. The performance proxies are used as Return on Assets (ROA), Return on Equity (ROE) and their standard deviations along with Net Interest Margin (NIM). Credit Risk is measured using Loan Loss Provision to Total Loans and advances (LLPTLA), Non-Performing Loan Ratio (NPLR), Capital Adequacy Ratio (CAR) and Credit to Deposit Ratio (CDR). Other variables considered are lagged dependent variable, dummy for comparison between $\mathrm{A}$ and $\mathrm{B}$ class and macroeconomic variables such as Gross Domestic Production (GDP) and Inflation Rates.

\begin{tabular}{|l|l|l|}
\hline \multicolumn{1}{|c|}{ Independent Variables } & \multicolumn{2}{c|}{ Dependent Variables } \\
\hline Lag of Dependent Variable & \multirow{5}{*n}{ LLPTLA } & ROA \\
\hline NPLR & & Standard Deviation of ROA (SDRoA) \\
\hline CAR & ROE \\
\hline CDR & & Standard Deviation of ROE (SDRoE) \\
\hline Dummy (A and B class BFIs) & & NIM \\
\hline GDP growth rate & \\
\hline Inflation & \\
\hline
\end{tabular}

Figure 1: Conceptual Framework

\section{METHODOLOGY}

This research is designed such a way that it establishes causal relationship between the credit risk and performance of two categories of banks with scientific approach. It is a quantitative research with the secondary data from Bank Supervision Report, Banking and Financial Statistics published by Nepal Rastra Bank and Annual reports of development banks. The population of this research is 28 commercial banks (as of 2019 November) and 11 national level development banks.

The study has considered panel data to address the probable issues arising from dissimilarities in the efficiency of management, work culture, risk taking and innovation although banks are supervised using same parameters by NRB. Further, Nepalese Banking system witnessed a major breakthrough in the last decade such as implementation of merger bylaws, shift from BASEL II to BASEL III, increment in the capital base, threshold of interest spread and revision, adoption of risk based supervision from compliance based supervision etc. In this 
context, this study has considered a time period from 2009 to 2019. Since, dependent variable is bank performance; ROA, ROE, Volatility of ROA and ROE and NIM; which correlates with their own past demands lagged independent variable. In addition, there may exist some heterogeneity demanding the need of Panel data to overcome the deficiencies of in model estimation which are prevalent in cross sectional and time series dimensions (Risal, 2019). Furthermore, panel data offers more degrees of freedom and less multicollinearity than cross-sectional and time-series data. The data is micro panel $(\mathrm{N}>>\mathrm{T})$ with $\mathrm{N}=39$ and $\mathrm{T}=11$. In such situation applying Dynamic Panel Data using GMM is considered as the best approach (Roodman, 2009).

In the equation form the model is given as:

$$
\text { Perf }_{\mathrm{it}}=\beta_{0}+\beta_{1} \text { Perf }_{\mathrm{it}-1}+\beta_{2} \text { LLPTLA }+\beta_{3} \text { NPLR }+\mathrm{B}_{4} \mathrm{CDR}+\beta_{5} \mathrm{CAR}
$$

Where,

Perf $=[$ ROA, ROE, SDROA, SDROE, NIM $]$

And, Loan Loss Provision to Total Loan assets (LLPTLA), Non-Performing Loan Ratio (NLPR), Credit to Deposit Ratio (CDR) and Capital Adequacy Ratio (CAR) are the independent variable. A single lag is added to overcome the endogeniety issue and further it implies that the present performance depends on past performance in some degree.

The model is estimated using Dynamic Panel Data model- Arellano Bond method, first published in 1991. As the performance of the current year is affected by the performance of the previous year, lagged variable is considered in the model. Another major reason behind including lagged dependent variable is making parsimonious model by eliminating the burden of estimating too many coefficients for lagged explanatory variables. The model exploits the restrictions of normal linear moment that follow assumption of no serial correlation in the errors, in an equation which contain individual effects, have lagged dependent variables and no exogenous variables (Arellano \& Bond, 1991). Dynamic Panel Models are consistent and include lagged levels of the dependent variables as regressor. Traditional static methods like fixed and random effects are static and inconsistent because of presence of endogenous regressor as well as correlated lags of independent variables (Mendoza \& Rivera, 2017).

In the above model, a dummy needs addition to measure the differences in impact on performance between A and B class of BFIs as they differ in terms of their capital base, riskiness and business operation. The dummy for Commercial Banks is assigned 1 whereas National Level development banks are assigned 0. 


$$
\text { Perf } \mathrm{fit}_{\mathrm{it}}=\beta_{0}+\beta_{1} \text { Perf }_{\mathrm{it}-1}+\beta_{2} \text { LLPTLA }+\beta_{3} \mathrm{NPLR}+\mathrm{B}_{4} \mathrm{CDR}+\beta_{5} \mathrm{CAR}+\beta_{6} \text { Dummy }
$$

As all these banks are operated in same macroeconomic environment, the model may not offer valid results, control variables (i.e., Real GDP growth rate and Inflation) have been added. Furthermore, to check the significance of the model and other issues that affect the accuracy of the model, Wald test has been performed. Finally, error term has been added to offer a robust model for the study as:

$$
\begin{aligned}
& \text { Perf }_{\mathrm{it}}=\beta_{0}+\beta_{1} \text { Perf }_{\mathrm{it}-1}+\beta_{2} \text { LLPTLA }+\beta_{3} \text { NPLR }+ \text { B }_{4} \text { CDR } \\
& +\beta_{5} \text { CAR }+\beta_{6} \text { Dummy }+\beta_{7} \text { GDP }+\beta_{9} \text { Inf }+\varepsilon_{\text {it }}
\end{aligned}
$$

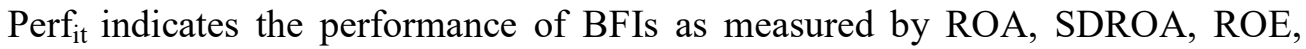
SDROE and NIM, Perf $f_{\text {it- } 1}$ indicates the lag effect of performance of past year in this year's performance of BFI. 'Similarly, 'it' in the subscript represents any bank in any particular year. B denotes coefficient.

The hypothesis for the study is:

H1: There is significant difference between impact of credit risk on performance of A and B class financial institutions in Nepal.

\section{EMPIRICAL ANALYSIS}

The analysis follows a systematic approach starting with the descriptive statistics to stationarity test using the Levin-Lin-Chu and Fisher-type test considering first lag order followed by regression analysis alongside Wald test.

Table 1: Descriptive Statistics

\begin{tabular}{llllll}
\hline Variable & Obs & Mean & Std. Dev. & Min & Max \\
\hline Bank & 390 & 20 & 11.26909 & 1 & 39 \\
Year & 390 & 70.5 & 2.875971 & 66 & 75 \\
ROA & 390 & 0.013462 & 0.011264 & -0.068 & 0.040133 \\
SDROA & 390 & 0.00361 & 0.00668 & 0 & 0.058407 \\
ROE & 390 & 0.168819 & 0.624268 & -0.51699 & 9.016275 \\
SDROE & 390 & 0.060782 & 0.421157 & 0 & 6.235601 \\
CAR & 390 & 0.118106 & 0.079771 & -0.3837 & 0.6929 \\
NPLR & 390 & 0.020786 & 0.038968 & 0 & 0.55 \\
NIM & 389 & 0.030684 & 0.019924 & -0.00824 & 0.308551 \\
LLPTLA & 390 & 0.018625 & 0.061747 & 0 & 0.89 \\
CDR & 390 & 0.755493 & 0.211434 & 0 & 1.219 \\
GDP & 390 & 4.59877 & 1.896715 & 0.588679 & 7.905742 \\
Inflation & 390 & 8.089119 & 2.274136 & 0 & 11.09482 \\
Dummy & 390 & 0.717949 & 0.450576 & 0 & 1 \\
\hline
\end{tabular}


The above table shows the descriptive statistics of both Commercial and Development Banks. There are 390 observations in each variable showing that the data is highly balanced. The mean ROA for banks is 0.013462 with standard deviation of 0.011264 . The mean standard deviation between pair-wise standard deviation of ROA stands at 0.00361 . The mean ROE is $16.88 \%$ with mean SDROE of 0.060782 . The mean CAR is 0.118 with Standard deviation of 0.0797 . The average NPLR is 0.021. The mean NIM, LLPTLA and CDR are 0.031, 0.0186 and 0.7554 with average GDP of $4.59 \%$ and average inflation of $8.08 \%$

\section{Stationarity Test}

Presence of unit root indicates that the panel data is generated from the integrated process which can lead to the spurious regression (Urbain and Westerlund, 2006). In this regard several test has been proposed for checking unit root test in panel data. The paper uses two standard test Levin, Lin and Chu (2002) and HarrisTzavalis (1999) for checking the presence of unit-root. Both test null hypothesis of presence of unit root. The results are tabulated below:

Table 2: Unit Root Test

\begin{tabular}{lllll}
\hline Variable & Levin, Lin Chu Test & \multicolumn{3}{l}{ Harris-Tzavalis } \\
\hline & Rho Statistics & P-Value & Rho Statistics & P-Value \\
\hline ROA & $-9.29 * * *$ & 0.000 & $0.2454^{* * *}$ & 0.000 \\
ROE & $-6.610^{* * *}$ & 0.000 & $0.3857^{* * *}$ & 0.000 \\
SDROA & $-11.13^{* * *}$ & 0.000 & $0.2302^{* * *}$ & 0.000 \\
SDROE & $-17.05^{* * *}$ & 0.000 & $-0.1826 * * *$ & 0.000 \\
NIM & $-15.78^{* * *}$ & 0.000 & $0.3861^{* * *}$ & 0.000 \\
CAR & $-40.71^{* * *}$ & 0.000 & $0.1954^{* * *}$ & 0.000 \\
NPLR & $-12.09^{* * *}$ & 0.000 & $0.0474^{* * *}$ & 0.000 \\
LLPTLA & $-10.24^{* * *}$ & 0.000 & $-0.0087^{* * *}$ & 0.000 \\
CDR & $-37.68^{* * *}$ & 0.000 & $0.4038^{* * *}$ & 0.000 \\
\hline
\end{tabular}

The above results in the table 2 shows all the variables of interest to be stationary.

\section{Return on Asset}

Table 3: Regression Results on ROA

\begin{tabular}{lll}
\hline ROA & Coefficient & $\mathrm{P}>\mathrm{z}$ \\
\hline ROA L1 & 0.250898 & $0 * * *$ \\
Dummy & 0.000773 & 0.216 \\
CAR & 0.018721 & $0 * * *$ \\
NPLR & -0.01122 & $0.013^{* *}$ \\
LLPTLA & -0.00709 & 0.283 \\
CDR & 0.004781 & $0 * * *$ \\
GDP & -0.00073 & $0 * * *$ \\
Inflation & -0.00058 & $0.001^{* * *}$ \\
\hline Note. The z statistics in parentheses $* \mathrm{p}<0.10, * * \mathrm{p}<0.05$ and $* * * \mathrm{p}<0.01$
\end{tabular}


The table shows the results of regression with ROA as dependent variable. The impact of ROA L1, NIM, CAR, NPLR, CDR, GDP, Inflation and B0it is significant on ROA as $\mathrm{p}>\mathrm{z}$ is less than 0.05 . The result indicates that 1 unit rise in CAR raises ROA by 0.018 units. NPLR moving 1 unit in positive direction will impact the ROA to move in the opposite direction by -0.0112 units. Similarly, 1 unit change in CDR will change ROA in same direction. GDP and Inflation, though being macroeconomic factors impact the ROA adversely. Even if all the variables in the model are null, the ROA still increase by 0.012107 units.

\section{Standard Deviation of Return on Asset}

\section{Table 4: Regression Results on SDROA}

\begin{tabular}{lll}
\hline SDROA & Coefficient & $\mathrm{P}>\mathrm{z}$ \\
\hline SDROA L1. & 0.151252 & $0 * * *$ \\
Dummy & -0.01008 & $0 * * *$ \\
CAR & 0.00056 & 0.807 \\
NPLR & 0.009396 & $0.084 *$ \\
LLPTLA & -0.00196 & $0 * * *$ \\
CDR & 0.004075 & $0 * * *$ \\
GDP & 0.000443 & $0 * * *$ \\
Inflation & 0.000917 & $0 * * *$ \\
\hline Note. The z statistics in parentheses $* \mathrm{p}<0.10, * * \mathrm{p}<0.05$ and $* * * \mathrm{p}<0.01$
\end{tabular}

The table shows the results of regression with SDROA as dependent variable. While ROA measures return as a measure of performance, SDROA measures risk as a measure of performance. The impact of SDROA L1, Dummy, LLPTLA, CDR, GDP, Inflation and B0it is significant on SDROA as $\mathrm{p}>\mathrm{z}$ is less than 0.05 . The result indicates that 1 unit increase in lag increases the SDROA by 0.051 units. The fact that a BFI is A class makes its risk lesser by 0.01 units. Similarly, 1 unit increase in LLTPLA decreased the risk as measured by SDROA by 0.0019 units. 1 unit upward movement in CDR will cause the SDROA to move in the same direction by 0.0041 units. Similarly, GDP and Inflation, have positive relationship with SDROA which imply that 1 unit increase in GDP and Inflation each increase the risk on assets. Even if all the variables in the model are null, the SDROA decreases by 0.00189 units. 


\section{Return on Equity}

Table 5: Regression results on ROE

\begin{tabular}{lll}
\hline ROE & Coefficient & $\mathrm{P}>\mathrm{z}$ \\
\hline ROE L1 & 0.721236 & $0 * * *$ \\
Dummy & 0.306324 & $0 * * *$ \\
CAR & -0.56348 & $0 * * *$ \\
NPLR & -0.21976 & 0.208 \\
LLPTLA & -4.04885 & $0 * * *$ \\
CDR & 0.070073 & 0.146 \\
GDP & -0.03728 & $0 * * *$ \\
Inflation & -0.02569 & $0 * * *$ \\
\hline Note. The z statistics in parentheses $* \mathrm{p}<0.10, * * \mathrm{p}<0.05$ and $* * * \mathrm{p}<0.01$
\end{tabular}

The table shows the results of regression with ROE as dependent variable. The impact of ROE L1, Dummy, CAR, LLPTLA, GDP, Inflation and B0it is significant on $\mathrm{ROE}$ as $\mathrm{p}>\mathrm{z}$ is less than 0.05 . The result indicates that 1 unit increase in lag increases the ROE by 0.721 units. The fact that a bank is an A class BFI makes its performance, i.e. ROE better by 0.306 units. 1 unit increase in CAR decreases the Return on equity by 0.563 units. Similarly, 1 unit increase in LLTPLA decreases the ROE by 4.05 units. Similarly, GDP and Inflation, have inverse relationship with ROE which imply that 1 unit increase in GDP and Inflation each decrease the return on equity. Even if all the variables in the model are null, the ROE increases by 0.277 units.

\section{Standard Deviation of Return on Equity}

Table 6: Regression Results on SDROE

\begin{tabular}{lll}
\hline SDROE & Coefficient & $\mathrm{P}>\mathrm{z}$ \\
\hline SDROE L1 & -0.21769 & $0 * * *$ \\
Dummy & -1.43376 & $0 * * *$ \\
CAR & 0.007396 & 0.771 \\
NPLR & 0.316503 & $0.003 * * *$ \\
LLPTLA & 3.151721 & $0 * * *$ \\
CDR & -0.04171 & $0 * * *$ \\
GDP & -0.00132 & $0.035^{* *}$ \\
Inflation & -0.0017 & $0.042^{* *}$ \\
\hline Note. The z statistics in parentheses $* \mathrm{p}<0.10, * * \mathrm{p}<0.05$ and & $* * * \mathrm{p}<0.01$
\end{tabular}

The table shows the results of regression with SDROE as dependent variable. While ROE measures return as a measure of performance, SDROE measures risk as a measure of performance. The impact of SDROE L1, Dummy, NPLR, LLPTLA, CDR, GDP, Inflation and B0it is significant on SDROE as $\mathrm{p}>\mathrm{z}$ is less than 0.05 . The result indicates that 1 unit increase in lag decreases the SDROE by 
0.218 units. The risk decreases by 1.43 units because of the fact that the given BFI is A class bank. There is positive relationship between NPLR and ROE with a coefficient of 0.316 units similarly, 1 unit increase in LLTPLA increases the risk by 3.152 units. 1 unit increase in CDR will decrease the SDROE by 0.0417 units. Similarly, GDP and Inflation, have adverse relationship with SDROE. Inflation, contradictory to the theory, is found to have negative relationship with variability of returns indicates that the banks perform better even in the inflationary situation. This relationship maybe interpreted as the heavy supply of money increases inflation and adjusted higher interest rates produce higher revenue and profitsleading to less volatility of Return on Equity. Here, if all the variables in the model are null, the SDROE decreases by 0.0017 units for 1 unit of increment in inflation

\section{Net Interest Margin}

Table 7: Regression Results on NIM

\begin{tabular}{lll}
\hline NIM & Coefficient & $\mathrm{P}>\mathrm{z}$ \\
\hline NIM L1 & 0.013218 & $0 * * *$ \\
Dummy & 0.014293 & $0 * * *$ \\
CAR & -0.01457 & 0.206 \\
NPLR & 0.099766 & $0 * * *$ \\
LLPTLA & 0.014815 & $0.002^{* * *}$ \\
CDR & 0.007341 & $0.018^{* *}$ \\
GDP & 0.001715 & $0 * * *$ \\
Inflation & 0.000963 & $0 * *$ \\
\hline Note. The $\mathrm{z}$ statistics in parentheses $* \mathrm{p}<0.10, * * \mathrm{p}<0.05$ and $* * * \mathrm{p}<0.01$
\end{tabular}

The table shows the results of regression with NIM as dependent variable. The impact of NIM L1, Dummy, NPLR, LLPTLA, CDR, GDP, Inflation and B0it is significant on NIM as $\mathrm{p}>\mathrm{z}$ is less than 0.05 . The result indicates that 1 unit increase in lag increases the NIM by 0.013 units. A class banks and financial institutions NIM is 0.014 units better than B class financial institutions. Similarly, NPLR and NIM have positive relationship. The NIM changes by 0.98 units in the same direction with 1 unit change in NPLR. 1 unit increase in LLTPLA increases NIM by 0.015 units. 1 unit change in CDR will cause the NIM to move in the same direction by 0.007 units. Similarly, GDP and Inflation, have positive relationship with NIM. It indicates that the increase in GDP growth leads to higher margin of interest rate. This could be because when GDP starts growing, market participants will seek more loans as the consumption pattern and business environment enhances. While the demand for loan increases, BFIs increase the lending rate which increases their interest margin. Here, if all the variables in the model are null, the NIM decreases by 0.001715 units when real GDP increases by 1 unit. 


\section{Wald Statistics}

Table 8: Wald Statistics

\begin{tabular}{lcllll}
\hline & ROA & \multicolumn{1}{c}{ SDROA } & \multicolumn{1}{c}{ ROE } & SDROE & NIM \\
\hline Wald chi2(8) & 5264.27 & 77491.55 & $6.57 \mathrm{E}+06$ & $1.01 \mathrm{E}+07$ & 2754.67 \\
Prob $>$ chi2 & $0 * * *$ & $0 * * *$ & $0 * * *$ & $0 * * *$ & $0 * * *$ \\
\hline Note. The chi2 statistics in parentheses $* \mathrm{p}<0.10, * * \mathrm{p}<0.05$ and $* * *$ & $\mathrm{p}<0.01$ &
\end{tabular}

The Wald statistics for the models applied show the $\mathrm{p}$ value to be significant at $1 \%$ level. This implies the significance of the model estimated and the results / outcomes can be analyzed and interpreted meaningfully (Risal, 2019).

\section{Bank Dummy}

Table 9: Comparison of A and B class banks

\begin{tabular}{lcc}
\hline $\begin{array}{l}\text { Effect of Bank Dummy on } \\
\text { Dependent Variables }\end{array}$ & Coefficient & $\mathrm{P}>\mathrm{z}$ \\
\hline ROA & 0.000773 & .216 \\
SDROA & -0.01008 & $0.000^{* * *}$ \\
ROE & 0.306324 & $0.000^{* * *}$ \\
SDROE & -1.43376 & $0.000^{* * *}$ \\
NIM & 0.014293 & $0.000^{* * *}$ \\
\hline Note. The z statistics in parentheses $* \mathrm{p}<0.10, * * \mathrm{p}<0.05$ and $* * * \mathrm{p}<0.01$
\end{tabular}

It is evident that the commercial banks are safer than development banks as they are less prone to risk captured by both the SDROA and SDROE, yet offer significantly higher ROE and fairly more NIM. However, there is no significant difference between the ROA of A and B class.

\section{DISCUSSIONS}

The study establishes a causal relationship between credit risk and performance of banks and with varying level of influence between A and B class of financial institutions. Hence, we can accept the alternate hypothesis which states that there is significant difference between impact of credit risk on performance of $\mathrm{A}$ and $\mathrm{B}$ class financial institutions in Nepal.

Bhattarai (2015) showed that NPLR has strong negative relation with ROA of commercial banks. Another study conducted by Isanzu (2011) shows similar findings. This study further reinforces it as the relationship between ROA and NPLR is found to be negative and significant. Noman, Pervin, Chowdhury, and Banna (2015) identified that CAR affects ROA positively and significantly. This study again aligns with the findings. This study also confirms the findings of 
Almekhlafi, Almekhlafi, Kargbo, and $\mathrm{Hu}$ (2016) that GDP and inflation are negatively correlated to ROA.

This study finds negative relationship of CAR with ROA which supports the findings of Mushtaq, Ismail, and Hanif (2015). Klomp and De Haan (2011) and Bouheni (2013) have stated that the Real GDP growth must contribute positively on banking performance and risk reduction because when GDP moves upward, the bank's level of business is likely rise, which in turn brings better earnings and returns. However, the findings of this study contradict with it. This study shows significant and negative relationship of GDP with return indicators, i.e. ROA, ROE and positive relationship with SDROA. However, in respect to SDROE and NIM, the findings align to that of Klomp and De Haan (2011) and Bouheni (2013).

CDR is found to increase both risk and return of banks in terms of ROA and SDROA. It has negative relationship with SDROE and positive with NIM. The study conducted by Parab and Patil (2018) shows positive and significant relationship of CDR with ROA, ROE and NIM. This study confirms the same however, the relationship with ROE is not found to be significant.

Research conducted in Jordan shows negative and significant relationship between LLPTLA and both ROA and ROE. (Ramadan, Kilani, \& Kuddumi, 2011). However, this study shows that LLPTLA and ROA do not have significant relationship whereas the relationship between ROE and LLPTLA confirms the findings of the research.

Risal (2018) has found adversely significant relationship of SDROA with CAR and positively significant relationship with NPLR. The findings of this study contradict with it as the relationship is found to be insignificant. Furthermore, Risal (2018) has identified insignificant relationship between SDROE and CAR. This study has found significant relationship between the two variables. This study reinforces the findings of Risal (2018) on the grounds of NPLR and SDROE as they are found to have significant positive relationship. Gale (2010) has identified CAR to be a prominent parameter to reduce risk of BFIs as it avoids fire sale of assets due to lack of adequate capital. However, this study didn't find significant relationship of Capital adequacy with risk parameters.

\section{CONCLUSION AND THE POLICY IMPLICATIONS}

The results show that the impact of credit risk differs among various variables in Commercial and Development Banks. Commercial banks are found to be less risky in term of credit risk measured by SDROA and SDROE. Further, findings imply that CAR has extreme impact on performance of both the classes of banks which validates the central bank's focus on CAR. However, excessively high 
capital reduces the ROE ( 1 unit increase in capital causes 0.56 unit decrease) and it demands attention over investment plans offering good return at lesser risk. From the findings, Commercial banks are recommended to monitor and maintain appropriate level of LLPTLA whereas Development banks are recommended to focus on CDR while CAR is found to have big impact on credit risk of both class financial institutions. Both the proxies of macroeconomic variables (i.e., Inflation and GDP) have very small or negative effect on performances of BFIs. It is as per ceteris paribus that the higher inflation deteriorates the performance of BFIs but negative influence of GDP is surprising as it may be due to the growth of other sectors. In-depth assessment on the contribution of control variables (i.e., Inflation and real GDP growth) is slightly beyond the scope of this study. Hence, it offers an opportunity for future researchers to deep dive into this contradiction caused by them on performance of BFIs.

This study has practical implications to regulators as well as the Management of BFIs. This study gives insights on which indicators to focus more to enhance profitability and reducing credit risk. It also gives broad view on the variables that affect $\mathrm{A}$ and $\mathrm{B}$ class institutions enabling regulators to be more precise with implementing regulatory policy and focus on certain variables more to mitigate the adverse impact of credit risk on performance of BFIs.

It is evident that CAR has positive impact on ROA but negative on ROE with no significant impact on other performance indicators. CAR, not just impacts the Bank's management but also the shareholders who have invested their money in the company expecting higher returns, though result suggests that increase $3 \mathrm{~d}$ capital base does not increase the returns to equity holders. BFIs should be aware to keep their CAR neither too low nor too high as it deteriorates ROE. Thus, the minimum capital requirements as per BASEL that NRB has implemented upon different categories of BFI seem to be validated. BFIs can prioritize their credit risk evaluation variables based on the findings of this research. Also, shareholders or potential investors can invest in BFIs by checking the credit risk of the BFIs based on this study.

For academicians and scholars intending to do their academic research on this field can take findings and methodology from this research as base and include in their literatures. This study confirms the Nepalese banking practice and policy of bringing the non-performing loan to be a commendable move and is also consistent with the theoretical underpinning that the decrease in NPLR decreases the risk for equity holders. Hence, management should ensure that their BFIs do not disappoint the investors and maintains a sound quality of assets only. Another important variable to be looked into and a proper balance to be maintained is CDR. Increase in CDR increases both risk as well as returns for the organization but decreases the variability of returns to equity holders. Hence, a clear cut 
demarcation and continuous monitoring would maximize the wealth at optimal level of risk. Finally, BFIs are encouraged to focus on managing these important variables of credit risk so as to ensure that no stakeholders of the BFIs face any disadvantageous situation. Furthermore, the study shows the concern of government toward regulating BFIs in parameters affecting credit risk such as CAR, NPLR and CDR is commendable.

\section{REFERENCES}

Ali, K., Akhtar, M. F., \& S. Sadaqat. 2011. Financial and non-financial business risk perspectives: Empirical evidence from commercial banks. Middle Eastern Finance and Economics, 11(11), 150-160.

Aliu, M., \& A. Sahiti. 2016. The effect of credit risk management on banks' profitability in Kosovo. European Journal of Economic Studies, 492-511.

Almekhlafi, E., Almekhlafi, K., Kargbo, M., \& X. Hu. 2016. A study of credit risk and commercial banks' performance in Yemen: Panel evidence. Journal of Management Policies and Practices, 57-69.

Arellano, M., \& S. Bond. 1991. Some tests of specification for panel data: Monte Carlo evidence and an application to employment equations. Review of Economic Studies, 277-297.

BAFIA. 2017. Bank and financial institution act, 2073. Kathmandu: Government of Nepal.

BASEL Committee on Banking Supervision. 2010. BASEL III: International framework for liquidity risk measurement, standards and monitoring.

BASEL committee. 2000. Principles for the management of credit risk. Retrieved from Bank for International Settlements: https://www.bis.org/publ/bcbs75.pdf

Bhattarai, Y. R. 2015. Effect of Credit Risk on the Performance of Nepalese Commercial Banks. NRB Economic Review, 42-64.

Fredrick, O. 2012. The Impact of Credit Risk Management on Financial Performance of Commercial Banks in Kenya. DBA Africa Management Review, 22-37.

Gale, D. 2010. The effects of bank capital on lending: What dowe know, and what does it mean? International Journal of Central Banking, 6(34), 187-204.

Gizaw, M., Kebede, M., \& S. Selvaraj. 2015. The impact of credit risk on profitability performance of commercial banks in Ethiopia. African Journal of Business Management, 9(2), 59-66. 
Harris, R. D., \& E. Tzavalis. 1999. Inference for unit roots in dynamic panels where the time dimension is fixed. Journal of econometrics, 91(2), 201-226.

Isanzu, J. S. 2017. The impact of credit risk on the financial performance of Chinese Banks. Journal of International Business Research and Marketing, 14-17.

Levin, A., Lin, C. F., \& C. S. J. Chu. 2002. Unit root tests in panel data: asymptotic and finite-sample properties. Journal of econometrics, 108(1), 1-24.

Kani, S. 2017. Credit risk and banks performance: Evidence from WAEMU countries. IOSR Journal of Economics and Finance (IOSR-JEF), 5-11.

Klomp, J., \& De Haan. 2011. Banking risk and regulation: Does one size fit to all? Journal of Banking and Finance, 36(12), 3197-3212.

Malla, B. K. 2017. Credit portfolio management in Nepalese commercial banks. The Journal of Nepalese Business Studies, 101-109.

Mendoza, R., \& J. P. Rivera. 2017. The effect of credit risk and capital adequacy on the profitability of rural banks in the Philippines. Scientific Annals of Economics and Business, 83-96.

Mushtaq, M., Ismail, A., \& R. Hanif. 2015. Credit risk capital adequacy and banks performance: Empirical evidence from Pakistan. International Journal of Financial Management, 27-32.

Nawaz, M., Munir, S., Ahad, S., Afzal, F., Asif, M., \& M. Ateeq. 2013. Credit risk and the performance of Nigerian Banks. Interdisciplinary Journal of Contemporary Research in Business, 49-63.

Noman, A. H., Pervin, S., Chowdhury, M. M., \& H. Banna. 2015. The effect of credit risk on the banking profitability: A case on Bangladesh. Global Journal of Management and Business Research, 41-48.

Olugboyega, K. S., Babatunji, S. A., Jayeola, O., \& B.A. Tobi. 2018. Effect of credit risk management on financial performance of Nigerian listed deposit money banks. Scholedge International Journal of Business Policy \& Governance, 5(06), 53-62.

Parab, C. R., \& M. Patil. 2018. Credit risk and public and private banks' performance in India: A panel approach. International Refereed Research Journal, 34-39.

Poudel, S. R. 2018. Assessment of credit risk in Nepali commercial banks. Journal of Applied and Advanced Research, 65-72.

Ramadan, I. Z., Kilani, Q., \& T. Kuddumi. 2011. Determinants of bank profitability: Evidence from Jordan. International Journal of Academic Research, 180-191. 
Risal, H. G., \& S.B. Panta. 2019. CAMELS- Based supervision and risk management: What works and what does not. FIIB Business Review, 194-204.

Roodman, D. 2009. How to do Xtabond2: An Introduction to Difference and System GMM in Stata. The Stata Journal, 9(1), 86-136. https://doi.org/10.1177/ $\underline{1536867 X 0900900106}$

Saeed, M. S., \& N. Zahid. 2016. The impact of credit risk on profitability of the commercial banks. Journal of Business \& Financial Affairs, 5(2), 2167-0234.

Urbain, J. P., \& J. Westerlund. 2006. Spurious regression in nonstationary panels with cross-unit cointegration. METEOR, Mastricht research school of Economics of TEchnology and ORganizations. 